\title{
Level of stress hormones in American mink with an evaluated behavioral profile based on an empathic test
}

\author{
DAMIAN ZIELIŃSKI, BRYGIDA ŚLASKA, IWONA ROZEMPOLSKA-RUCIŃSKA \\ Institute of Biological Bases of Animal Production, Faculty of Biology, Animal Sciences and Bioeconomy, \\ University of Life Sciences, Akademicka 13, 20-950 Lublin, Poland
}

\section{Zieliński D., Ślaska B., Rozempolska-Rucińska I. \\ Level of stress hormones in American mink with an evaluated behavioral profile based on an empathic test}

Summary

The aim of the study was to assess the level of stress hormones (cortisol and testosterone) in the blood of minks with a known behavioral profile based on the empathic test. The research was conducted on 100 oneyear-old American mink (Neovison vison) females. The empathic test was performed according to the method described by Malmkvist and Hansen (2002) in triplicate with a two-week pause between tests. The test consisted of inserting a wooden stick into the living space of the animal. Animals were classified into four behavioral profiles: aggressive, curious, fearful and neutral. In the evaluation of stress level, the levels of testosterone and cortisol in postmortem blood were determined. Blood levels of testosterone $(\mathrm{ng} / \mathrm{ml})$ and cortisol $(\mathrm{ng} / \mathrm{ml})$ were determined by the ELFA method (Enzyme Linkes Fluorescent Assay). It has been shown that the behavioral profile of mink had no significant effect on the levels of testosterone and cortisol in the mink blood. Cortisol levels were similar in animals from all four behavioral profiles $(40.6$ to $46.0 \mathrm{ng} / \mathrm{ml})$. The lowest level of testosterone was found in animals evaluated in the empathic test as aggressive and fearful $(0.056 \mathrm{ng} / \mathrm{ml}$ and $0.071 \mathrm{ng} / \mathrm{ml}$, respectively). Post mortem sampling reduces the effect of stress resulting from the blood collection itself, but the results of the study indicate that the determination of stress hormone levels in postmortem blood was a non-differentiating characteristic in the context of their behavioral profile.

Keywords: American mink, behavior, stress hormones

Measurement of so-called stress hormones (e.g. cortisol, testosterone, and adrenaline) plays an important role in the assessment of the phenomenon of adaptation and stress in animals, despite the fact that the levels of these hormones are differentiated individually and depend on the temperament of the individual $(2,3$, 12). The secretion of endogenous glucocorticoids by the adrenal cortex is controlled by the biological clock and may be increased at any time by stress stimulation (12). The level of stress hormones are also affected by various environmental factors associated with the rearing conditions $(1,16,17)$, transportation (15), diet and the condition of the animal (14). The level of these hormones may vary depending on the method used to collect the biological material for their evaluation. Most often these hormones are determined from blood samples, and blood sampling from animals is a strong stressor, which can significantly reduce the reliability of the obtained results (14). In addition to blood, the concentration of steroid hormones is also determined from urine, feces, saliva and hair $(6,7,14)$.

Collecting of blood samples for the determination of hormone levels involves the need to immobilize the animal, which results in different levels of stress during the immobilization of a mink and thus may have a significant effect on the level of these hormones in the blood system. Behavioral reactions are highly correlated with the activity of physiological systems, which affects the functions of the brain as well as the autonomic nervous system $(8,9)$. The disturbance of the natural psychosocial homeostasis (stressors) is a signal to activate adaptive mechanisms to a new, altered environment. This adaptation is a behavioral response which is coupled with increased stress hormone synthesis (adrenaline, noradrenaline and cortisol) (12). 
In the modern approach to animal welfare fur is associated with the assessment of the temperament of the breeding herd. Behavioral tests are used for this purpose. A good tool for assessing mink temperament is the empathic test (stick test) that evaluates a mink as timid, curious, aggressive and uncertain (5). The response of the animals to the introduced object through the mesh of the cage serves as a measure of the positive emotional state of the mink $(11,17)$. This test was validated as an indicator of American mink temperament (10), which reflects their general emotional state (8). Moreover, it is listed in the Welfur project as a useful tool in the assessment of animal behavior (11).

The purpose of this study was to determine if there were differences in the level of stress hormones in mink blood depending on their emotional reactivity determined by empathic tests.

\section{Material and methods}

The study was conducted on 100 one-year-old American mink females (Neovison vison) reared on a farm of carnivorous fur animals at the Experimental Station of the National Research Institute of Animal Production in Chorzelów. These animals took part in the study of Zieliński et al. (17). None of the animals selected for testing displayed stereotypical behavior. The animals were kept singularly in standard mink cages with a wooden nesting and fed according to the standards for carnivorous fur animals. The maintenance and feeding conditions of the farm in the period did not change. The study was carried out with the consent of the Second Local Committee for Experiments on Animals in Lublin (NR75/2014).

An empathic test (commonly called a „stick” test) was used to determine the behavioral profile of mink according to the method described by Malmkvist and Hansen (8). The procedure, performed in triplicate, consisted in inserting the object (wooden stick) into the cage through the mesh of the cage over the nest box for 30 seconds in each repetition. The observer assessed the animal's immediate response to the object introduced into the living space. The behavioral response of each individual was determined separately for each of the three replicates. Based on the final assessment of their behavioral profile the animals were classified into aggressive, curious, fearful and neutral groups.

In the evaluation of mink stress, the levels of testosterone $(\mathrm{ng} / \mathrm{ml})$ and cortisol $(\mathrm{ng} / \mathrm{ml})$ in post mortem blood samples were determined. Hormone levels were determined by ELFA (Enzyme Linked Fluorescent Assay) with detection limit: for testosterone $0.05 \mathrm{ng} / \mathrm{ml}$, for cortisol $2.0 \mathrm{ng} / \mathrm{ml}$.

Hormone levels depending on the profile of behavioral mink determined using analysis of variance, the method of least squares, using the SAS statistical package (version 9.4 by SAS Institute Inc., Cary, NC).

The probability of assignment of a specific hormone level was analyzed by multivariate analysis of variance using the least squares method, taking into account the behavioral profile of tested animals. The calculations were made using SAS statistical package (SAS Institute, Cary, NC, USA). The values of the analyzed hormone levels are shown as least square means (1sm), providing standard errors (se) that determine the reliability of estimation.

\section{Results and discussion}

Analysis of the empathic test have shown that the tested animals were characterized by four behavioral profiles: aggressive, curious, fearful and neutral. It has been shown that the behavioral profile of mink had no significant effect on the levels of testosterone and cortisol in the mink blood (Fig. 1, Fig. 2). Cortisol levels were similar in animals from all four behavioral profiles ( 40.6 to $46.0 \mathrm{ng} / \mathrm{ml}$ ). The lowest level of testosterone was found in animals evaluated in the empathic test as aggressive and curious $(0.056 \mathrm{ng} / \mathrm{ml}$ and $0.071 \mathrm{ng} / \mathrm{ml}$, respectively). Moreover, a negative correlation was found between testosterone and cortisol levels $(r=-0.16 p<0.17)$.

The level of both tested hormones was similar, despite the different response of the animals to the new object in the cage introduced during the empathic test (Fig. 1, Fig. 2). In the studies of Gorajewska et al. $(2,3)$, animals with a trusting type of behavior were characterized by a lower cortisol levels in response to stress, compared to timid animals. The study also showed that there was a change in cortisol levels with subsequent tests. Positive cortisol levels in confident animals have been demonstrated in a variety of behavioral tests. In trustful animals in a variety of behavioral

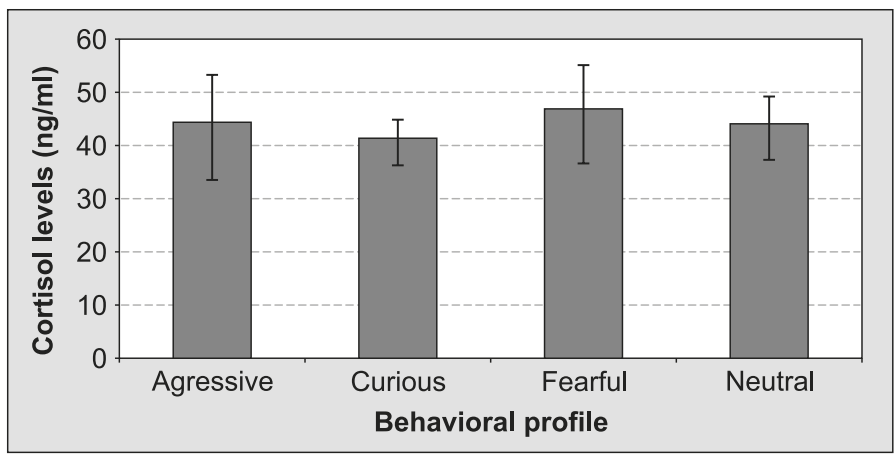

Fig. 1. Cortisol level in blood of American mink (Neovison vison) with determined behavioral profile

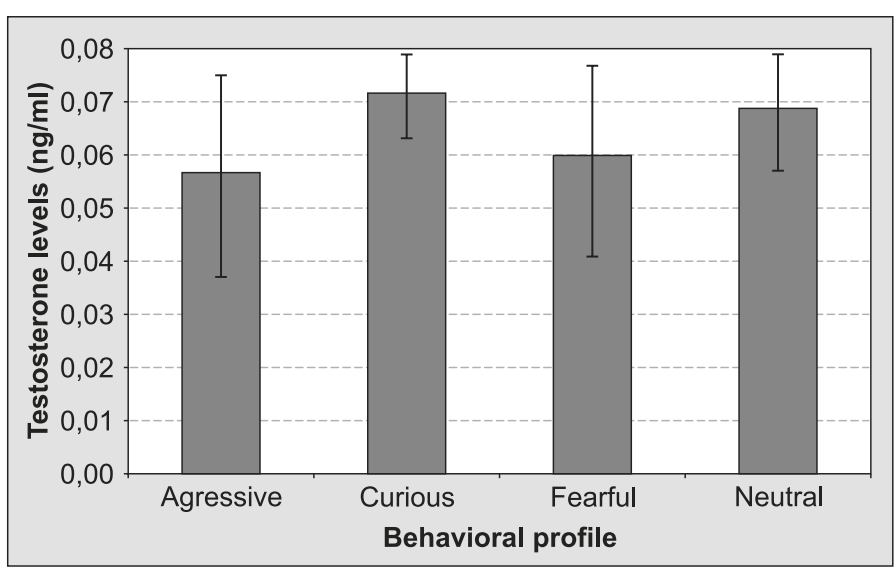

Fig. 2. Testosterone level in blood of American mink (Neovison vison) with determined behavioral profile 
tests lower cortisol levels have been demonstrated (2, $3)$. The cortisol level in curious animals was the lowest among all the distinguished behavioral types, which is consistent with the results of other authors (4).

Studies on the level of hormones in the body of minks are usually carried out with samples taken from saliva or blood. This involves the necessity of grasping and immobilizing the animal, which can significantly affect the level of specific hormones (16). Post mortem sampling reduces the effect of stress resulting from immobilization as well as the saliva/blood collection itself. However, the results of this study indicate that the stress hormone levels in the blood collected post mortem were non-differentiated in the context of the behavioral profile of the tested animals.

\section{References}

1. Barabasz B., Fortuńska D., Gacek L.: Behavioural and physiological responses of nutria to different housing systems. Ann. Anim. Sci. 2011, 2, 179-186.

2. Gorajewska E., Filistowicz A., Nowicki S., Przysiecki P.: Physiological level of cortisol and testosterone in the blood of Arctic fox females. Med. Weter. 2015, 71, 10, 638-642.

3. Gorajewska E., Filistowicz A., Nowicki S., Przysiecki P., Czyz K.: Hormona response of Arctic fox females to short-and long-term stress. Vet. Med. 2015, $60,3,147-154$.

4. Gulevich R. G., Oskina I. N., Shikhevich S. G., Fedorova E. V., Trut L. N.: Effect of selection for behavior on pituitary-adrenal axis and proopiomelanocortin gene expression in silver foxes (Vulpes vulpes). Physiol. Behav. 2004, 82, 2-3, 513-518.

5. Hansen S. W., Møller S. H.: The application of a temperament test to on-farm selection of mink. Acta Agric. Scand. A Anim. Sci. 2001, 51, 93-98.
6. Koren L., Mokady O., Geffen E.: Social status and cortisol levels in singing rock hyraxes. Horm. Behav. 2008, 54, 1, 212-216.

7. Malmkvist J., Brix B., Henningsen K., Wiborg O.: Hippocampal neurogenesis increase with stereotypic behavior in mink (Neovison vison). Behav. Brain Res. 2012, 229, 2, 359-364.

8. Malmkvist J., Hansen S. W.: Generalization of fear in farm mink, Mustela vison, genetically selected for behaviour towards humans. Anim. Behav. 2002, 64, 487-501.

9. Malmkvist J., Hansen S. W., Damgaard B. M.: Effect of the serotonin agonist buspirone on behaviour and hypothalamic-pituitary-adrenal axis in confident and fearful mink. Physiol. Behav. 2003, 78, 2, 229-240.

10. Meagher R. K., Duncan I., Bechard A., Mason G. J.: Who's afraid of the big bad glove? Testing for fear and its correlates in mink. Appl. Anim. Behav. Sci. 2011, 133, 3, 254-264.

11. Mononen J., Møller S. H., Hansen S. W., Hovland A. L., Koistinen T., Lidfors L., Ahola $L .:$ The development of on-farm welfare assessment protocols for foxes and mink: the WelFur project. Animal Welf. 2012, 21, 3, 363-371.

12. Möstl E., Palme R.: Hormones as indicators of stress. Domest. Anim. Endocrinol. 2002, 23, 1-2, 67-74.

13. Pedersen V., Jeppesen L. L., Jeppesen $N$.: Effects of group housing systems on behaviour and production performance in farmed juvenile mink (Mustela vison). Appl. Anim. Behav. Sci. 2004, 88, 1-2, 89-100.

14. Sorensen B., Clausen T. N., Wamberg S., Hansen O.: Physiological changes in mink (Mustela vison) dams subjected to weaning at different times during lactation. Acta Agric. Scand. A Anim. Sci. 2001, 51, 2, 148-154.

15. Śmiecińska K., Denaburski J., Sobotka W.: Slaughter value, meat quality, creatine kinase activity and cortisol levels in the blood serum of growingfinishing pigs slaughtered immediately after transport and after a rest period. Pol. J. Vet. Sci. 2011, 14, 1, 47-54.

16. Tsai P. P., Schlichtig A., Ziegler E., Ernst H., Haberstroh J., Stelzer H. D., Hackbarth $H$.: Effects of different blood collection methods on indicators of welfare in mice. Lab anim. 2015, 44, 8, 301-310.

17.Zieliński D., Ślaska B., Rozempolska-Rucińska I., Zoń A.: In-depth analysis of the emotional reactivity of American mink (Neovison vison) under behavioral tests. Can. J. Anim. Sci. 2019, 99, 24-32, https://doi.org/10.1139/ CJAS-2018-0021.

Corresponding author: Damian Zieliński, PhD, Akademicka 13, 20-950 Lublin, Poland; e-mail: damian.zielinski@up.lublin.pl 